\title{
Hereditary optic atrophy with onset in early childhood
}

\author{
J. D. BRODRIGK
}

Sheffield

Duke-Elder and Scott (197I) classified hereditary optic atrophy into three groups:

(I) Unassociated with either systemic or neurological manifestations, including congenital or infantile optic atrophy, late onset optic atrophy, and Leber's disease.

(2) With widespread systemic and neurological manifestations, including Behr's infantile optic atrophy, the cerebellar ataxias of Marie and Friedrich, familial spastic paraplegia, and the lipidoses.

(3) Associated with craniostenosis.

A child with defective vision was recently found to belong to a family with a history of severely defective vision extending back for several generations. Some of the adult male members of this family had previously been diagnosed as suffering from Leber's disease. In view of the recent success in treating Leber's optic atrophy (Chisholm, Brontë-Stewart, and Foulds, ${ }_{1967}$; Foulds, Chisholm, Brontë-Stewart, and Wilson, I969; Watson-Williams, Bottomley, Ainley, and Phillips, I969), it was felt that further investigation of this family was warranted with a view to a trial of hydroxocobalamin in an attempt to improve their visual state.

\section{Methods}

Twenty individuals were examined personally. Each patient had a general medical and neurological examination. Ophthalmological examination consisted of estimation of visual acuity and refraction, visual field examination with the tangent screen, perimeter, and Friedman Analyser, clinical examination of the globe and adnexa, biomicroscopy, and fundus examination with the direct, binocular, and indirect ophthalmoscopes and the Hruby lens. Retinal abnormalities were photographed with a Kowa camera. $40 \mathrm{ml}$. blood were taken from each patient, centrifuged, and stored in plastic containers at $-15^{\circ} \mathrm{C}$. until used.

Three selected patients (the selection being governed by age, availability, and co-operation) were referred for EEG, ERG, and EOG examination, but their parents would consent only to the EEG examination.

\section{Results}

GENETIC STUDY

The pedigree is illustrated in the Figure. The known history extends back for six generations and involves 47 individuals; 22 of these ( 14 men and 8 women) are known to have been affected, the others having normal sight or their status being unknown. 37 members of the family survive ( 17 being normal and 20 affected); eight in the United States were not available for study and a further nine in Great Britain were either not available or uncooperative. The pedigree is summarized in Table I. 
Table I Summary of pedigree

\begin{tabular}{|c|c|c|c|c|c|c|c|c|}
\hline \multirow[t]{3}{*}{ Series } & \multirow{3}{*}{$\begin{array}{l}\text { No of } \\
\text { generations }\end{array}$} & \multirow{3}{*}{$\begin{array}{l}\text { Total } \\
\text { subjects }\end{array}$} & \multicolumn{6}{|c|}{ Affected } \\
\hline & & & \multicolumn{2}{|l|}{ res } & \multicolumn{2}{|l|}{ No } & \multicolumn{2}{|c|}{ Not known } \\
\hline & & & Male & Female & Male & Female & Male & Female \\
\hline $\begin{array}{l}\text { Whole } \\
\text { family }\end{array}$ & 6 & 47 & 14 & 8 & 12 & 8 & 4 & I \\
\hline $\begin{array}{l}\text { Cases } \\
\text { studied }\end{array}$ & 3 & 20 & $\underbrace{6}$ & & $\underbrace{4}_{8}$ & 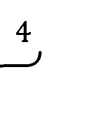 & o & 0 \\
\hline
\end{tabular}

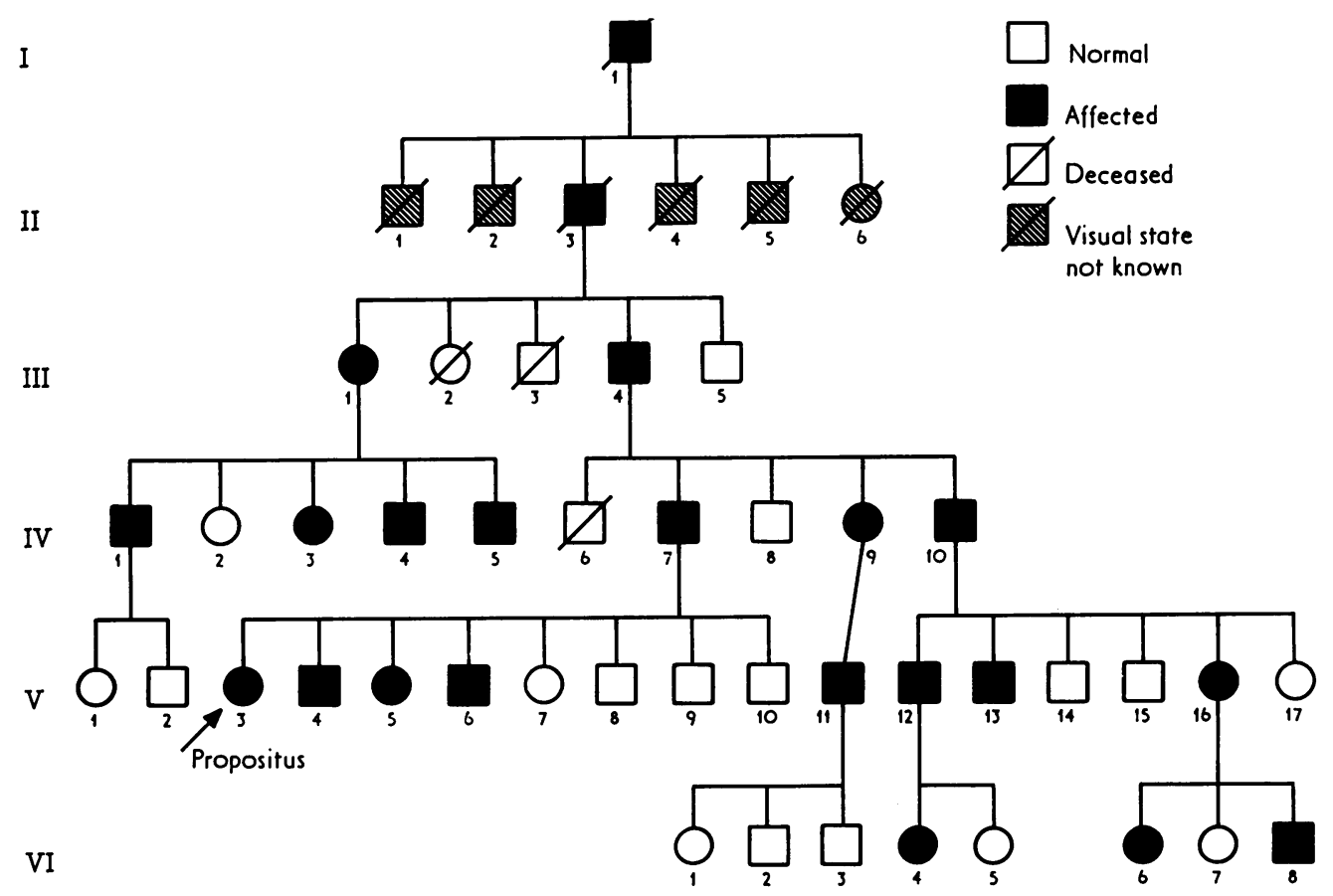

FIGURE Pedigree of family with hereditary optic atrophy, showing autosomal dominant transmission

GLINIGAL STUDY

In all the affected cases the onset had occurred between the ages of 5 and 7 years. Visual failure had occurred rapidly and was not associated with any systemic or neurological symptoms. The degree of visual impairment varied but was severe in all the affected cases.

General examination revealed no abnormalities apart from mild diabetes in Case IV.7 (Figure).

Ocular examination in the affected individuals revealed in most cases advanced optic atrophy with chalk-white discs but no evidence of cupping. The retinal vessels were normal in all the patients and there was no retinopathy. In five cases (IV.9, V.I I, V.I6, VI.2, and VI.6), the foveal reflex was extremely poor in each eye (Table II). In one of these 
Table II Clinical particulars of twenty subjects studied (twelve affected and eight normal)

\begin{tabular}{|c|c|c|c|c|c|c|c|}
\hline \multirow{2}{*}{$\begin{array}{l}\text { Pedigree } \\
\text { no. }\end{array}$} & \multirow[t]{2}{*}{ Sex } & \multirow{2}{*}{$\begin{array}{l}\text { Age } \\
(y r s)\end{array}$} & \multicolumn{2}{|c|}{ Visual acuity } & \multirow{2}{*}{$\begin{array}{l}\text { Age at } \\
\text { onset } \\
(y r s)\end{array}$} & \multirow{2}{*}{$\begin{array}{l}\text { Optic } \\
\text { discs }\end{array}$} & \multirow{2}{*}{$\begin{array}{l}\text { Fundus } \\
\text { appearances }\end{array}$} \\
\hline & & & Right & Left & & & \\
\hline IV, 7 & $\mathbf{M}$ & 45 & $3 / 60$ & $2 / 60$ & 6 & $\begin{array}{l}\text { Temporal } \\
\text { pallor }\end{array}$ & Normal \\
\hline IV, 9 & F & 52 & $\mathrm{CF}_{2}{ }^{\prime}$ & $\mathrm{CF}_{3}{ }^{\prime}$ & 6 & Atrophic & Poor foveal reflex \\
\hline $\mathrm{V}, 3$ & $\mathbf{F}$ & 19 & $6 / 24$ & $6 / 36$ & 7 & Pale & Pigmentary stippling \\
\hline $\mathrm{V}, 4$ & $\mathbf{M}$ & 15 & $6 / 36$ & $6 / 36$ & 5 & Pale & Normal \\
\hline$V, 5$ & $\mathbf{F}$ & 14 & $6 / 60$ & $6 / 36$ & 5 & Atrophic & Normal \\
\hline $\mathrm{V}, 6$ & $\mathbf{M}$ & 12 & $6 / 60$ & $3 / 60$ & 6 & Atrophic & Normal \\
\hline $\mathrm{V}, 7$ & $\mathrm{~F}$ & II & $6 / 5$ & $6 / 5$ & - & - & Pigment epithelium defect \\
\hline $\mathrm{V}, 8$ & $\mathbf{M}$ & 10 & $6 / 5$ & $6 / 5$ & - & - & Pigment epithelium defect \\
\hline $\mathrm{V}, 9$ & $\mathbf{M}$ & 8 & $6 / 6$ & $6 / 6$ & - & - & Pigment epithelium defect \\
\hline $\mathrm{V}$, io & $\mathbf{M}$ & 4 & $6 / 9$ & $6 / 9$ & - & - & Pigment epithelium defect \\
\hline $\mathrm{V}, \mathrm{II}$ & $\mathbf{M}$ & 28 & CF $6^{\prime}$ & CF $6^{\prime}$ & 5 & $\begin{array}{l}\text { Temporal } \\
\text { pallor }\end{array}$ & $\begin{array}{l}\text { Poor foveal reflex } \\
\text { white dots round maculae }\end{array}$ \\
\hline $\mathrm{V}, \mathrm{I} 2$ & $\mathbf{M}$ & $2 j$ & $4 / 60$ & $4 / 60$ & 6 & Pale & Normal \\
\hline $\mathrm{V}, \mathrm{I} 6$ & $\mathbf{F}$ & $3^{8}$ & $6 / 36$ & $6 / 36$ & 6 & Pale & Poor foveal reflex \\
\hline VI, I & $\mathbf{F}$ & 4 & $6 / 6$ & $6 / 6$ & - & - & Normal \\
\hline $\mathrm{VI}, 2$ & $\mathbf{M}$ & 3 & Unob & nable & - & - & Poor foveal reflex \\
\hline VI, 3 & $\mathbf{M}$ & $8 / 12$ & Unob & nable & 一 & - & Pigment epithelium defect \\
\hline VI, 4 & $\mathbf{F}$ & 4 & Unob & nable & - & Pale & Normal \\
\hline VI, 5 & $\mathrm{~F}$ & $I \frac{1}{2}$ & Unob & nable & 一 & - & Normal \\
\hline VI, 6 & $\mathbf{F}$ & 9 & $6 / 36$ & $6 / 36$ & 5 & Pale & $\begin{array}{l}\text { Poor foveal reflex } \\
\text { Pigmentary stippling }\end{array}$ \\
\hline VI, 8 & $\mathrm{~F}$ & I3 & $6 / 36$ & $6 / 36$ & 5 & Pale & Pigmentary stippling \\
\hline
\end{tabular}

cases (V.I I ), there was an accumulation of small white dots round both maculae. In three cases (V.3, VI.6, and VI.8), there was a delicate fine pigment stippling round the maculae which became somewhat coarser and more pronounced towards the periphery. There was no bone corpuscular formation or perivascular pigment sheathing.

Visual field examination revealed large central scotomata in all cases.

The unaffected cases who were old enough for subjective testing all had a visual acuity of $6 / 5$ with normal peripheral and central fields. No ocular abnormality was demonstrable in any of the unaffected cases apart from a rather prominent choroidal pattern and a slightly mottled appearance of the fundus in Cases V.7, V.8, V.9, V.ro, and VI.3.

The intraocular pressure in all cases was normal (applanation).

\section{BIOCHEMICAL STUDY}

Full blood count, erythrocyte sedimention rate, liver function tests, Wassermann reaction, Serum $B_{12}$, and serum folate were normal in all cases. Serum thiocyanate estimation was done by the technique described by Bowler (1944) and no measurable thiocyanate was detected in any patient.

Serum copper and zinc estimations were carried out on the affected cases and the results are shown in Table III (overleaf.) 
Table III Serum copper and zinc estimations in nine subjects

\begin{tabular}{|c|c|c|}
\hline $\begin{array}{l}\text { Pedigree } \\
\text { no. }\end{array}$ & $\begin{array}{l}\text { Serum copper } \\
(\mu \mathrm{g} . / \mathrm{I} 00 \mathrm{ml} .)\end{array}$ & $\begin{array}{l}\text { Serum zinc } \\
(\mu g . / 100 \mathrm{ml} .)\end{array}$ \\
\hline IV, 7 & 86 & 50 \\
\hline $\mathrm{V}, 3$ & 108 & 96 \\
\hline $\mathrm{V}, 4$ & 72 & 108 \\
\hline $\mathrm{V}, 5$ & 56 & 88 \\
\hline $\mathrm{V}, 6$ & 60 & 100 \\
\hline $\mathrm{V}$, io & 90 & 80 \\
\hline $\mathrm{V}, \mathrm{I} 2$ & 96 & 47 \\
\hline $\mathrm{V}, \mathrm{I} 6$ & I 68 & 36 \\
\hline VI, 4 & 90 & 50 \\
\hline Normal range & $70-140$ & $65-120$ \\
\hline
\end{tabular}

\section{ELEGTROENGEPHALOGRAPHY}

Three cases were selected for EEG studies, one of the least severely affected (V.4), one moderately affected (V.5), and one severely affected (V.6).

(I) Case V.4 had a record showing a well-maintained 12 c.p.s. alpha rhythm which responded in the normal way to eye opening and closing. There was a little added low amplitude slow activity throughout. The response to hyperventilation and photic stimulation was within normal limits, and transverse arrays showed no evidence of any focal lesion. (2) Case V.5 had a record which showed a little irregular alpha rhythm at rates around I 2 c.p.s.; there was constant low amplitude slow activity mostly in the theta range and a good deal of added generalized fast activity. There was no significant response to hyperventilation, but on photic stimulation there was a marked following of the flash frequency in both occipital regions.

(3) Case V.6 had a record which showed a very unstable alpha rhythm at rates between Io and 12 c.p.s. There was a good deal of added slow activity in both the delta and theta ranges and during hyperventilation moderate amplitude spikes were seen in both parietal regions. Bursts of generalized spike activity were also present later. There was no response whatever to photic stimulation, and opening and closing the eyes did not affect cerebral activity in any way.

\section{Discussion}

Examination of the pedigree of this family reveals a straightforward autosomal dominant transmission for the following reasons:

(I) Direct transmission occurs from both mothers and fathers to both sons and daughters and the transmission has a generally "vertical" distribution in the pedigree.

(2) No generation is missed out.

(3) The number affected (22) does not differ statistically from the number unaffected (20) plus not known (5) (=25).

(4) There are fourteen affected males and eight affected females. This does not differ statistically from the expected eleven of each.

The clinical findings in all the affected patients were virtually identical. The onset of visual symptoms had consistently occurred between 5 and 7 years and the visual acuity 
ranged from counting fingers at i foot to 6/36, with large central field defects in all individuals. Marginally poorer vision was found in those with a poor foveal reflex, and the overall poorer visual acuities were found in the older patients suggesting that a slowly progressive deterioration occurs over a number of years.

The pigmentary stippling and white spots seen in some fundi bore a marked resemblance to the fundus appearances described in Leber's optic atrophy (Duke-Elder and Dobree, I967), but there were no other clinical similarities.

There did not appear to be any consistent precipitating factors apart from one branch of the family in which the onset of visual symptoms in several individuals followed a severe attack of measles.

It has been established elsewhere that, in the children and non-smoking members of families with Leber's disease, an increase in the cyanide content of the body can occur after urinary tract infections with $E$. coli or Ps. pyocyaneus. This cyanide build-up overloads the already impaired cyanide-detoxicating mechanism and precipitates the onset of visual deterioration (Smith, I96r ; Wilson, I963). There is no evidence to suggest a similar neurotoxic mechanism with the measles virus, so that even had the diagnosis of Leber's disease been confirmed one must assume this apparent association to be fortuitous.

In eight instances the unaffected cases showed a markedly defective pigment epithelium which became much more evident towards the periphery. Whilst this could well be of no significance, it could perhaps be evidence of incomplete penetrance.

The biochemical assays revealed no measurable thiocyanate in any patient, elevated serum copper in one (V.i6), low serum copper in two (V.5 and V.6), and low serum zinc in four (IV.7, V.I2, V.I6, and VI.4). It is difficult, however, to ascribe any precise significance to these copper and zinc estimations.

The EEG records show a dramatic change in pattern from the immature but probably normal record of V.4, through the somewhat unstable record, possibly due to tension, in V.5, to the grossly abnormal record of V.6. These records show several similar features, in that all exhibit a rather rapid and unstable alpa activity. There is also a definite gradation between V.4, where the photic response is within normal limits, V.5, where it is fair, and V.6, where it is non-existent. These varying features of the EEG correlate with the degree of visual impairment.

Whilst the diagnosis of Leber's optic atrophy was still under consideration, it was decided to commence treatment with hydroxocobalamin which has been shown to produce a dramatic improvement in Leber's disease and tobacco amblyopia by its cyanide-binding capacity (Chisholm and others, I967; Foulds and others, r969; Watson-Williams and others, I969). Although this diagnosis was eventually discarded, it was decided to continue treatment on an empirical basis but no improvement was noted after 12 months' therapy.

Two important points emerge from a study of this family. In the first case misdiagnosis of the older members had labelled this family as suffering from Leber's disease and this was the diagnosis they volunteered when asked what was wrong with them. Because of this, false hopes were raised in their minds when hydroxocobalamin was introduced and received publicity for its beneficial results in treating Leber's optic atrophy.

The second consideration is that it is vitally important to document such families as accurately as possible so that education is planned from the start along the most beneficial lines and a change from normal to partially sighted school is avoided with its resulting retardation of the child's educational programme. With the accurate diagnosis of dominant hereditary optic atrophy with onset between 5 and 7 years, these children should all have commenced their education in a blind school. 


\section{Summary}

A family with dominant hereditary optic atrophy has been studied and the clinical, genetic, and biochemical findings described. EEG examination showed some minor abnormalities although there were no associated neurological features.

It is emphasized that misdiagnosis can result in abortive attempts at treatment with its resulting frustrations and that careful assessment of the onset and ultimate severity of the condition should be made in order to plan the most satisfactory system of education for the affected children.

\section{References}

BOWLER, R. G. (1944) 7. Biochem., 38, 385

CHISHOLM, I. A., BRONTË-STEWART, J., and FOULDS, w. s. (1967) Lancet, 2, 450

DUKE-ELDER, s., and DOBREE, J. H. (1967) "System of Ophthalmology", vol. Io, "Diseases of the Retina", p. 654. Kimpton, London and scotT, G. I. (197I) Idem., vol. I 2, "Neuro-ophthalmology", p. 228

Foulds, w. s., Chisholm, I. A., BRontë-STEWARt, J., and wilson, т. м. (I969) Bıtt. F. Ophthal., 53, 393

SMITH, A. D. M. (196I) Lancet, I, IOOI

WATson-Williams, E. J., Bottomley, A. G., Ainley, R. G., and Phillips, c. I. (1969) Brit. F. Ophthal.,

53, 549

WILSON, J. (1963) Brain, 86, 347 